Article

\title{
Organizing Sport for Climate Related Adaptations: Lessons from the Water and Forestry Industries
}

\author{
Cheryl Mallen ${ }^{1, *(1)}$ and Greg Dingle ${ }^{2}$ \\ 1 Department of Sport Management, Brock University, St. Catharines, ON L2S 3A1, Canada \\ 2 Department of Management, Sport and Tourism, La Trobe University, Melbourne 3086, Australia; \\ g.dingle@latrobe.edu.au \\ * Correspondence: cmallen@brocku.ca
}

check for

updates

Citation: Mallen, C.; Dingle, G.

Organizing Sport for Climate Related Adaptations: Lessons from the Water and Forestry Industries. Sustainability 2021, 13, 10462. https://doi.org/ $10.3390 /$ su131810462

Academic Editor: Giuseppe Battaglia

Received: 23 August 2021

Accepted: 15 September 2021

Published: 20 September 2021

Publisher's Note: MDPI stays neutral with regard to jurisdictional claims in published maps and institutional affiliations.

Copyright: (c) 2021 by the authors. Licensee MDPI, Basel, Switzerland. This article is an open access article distributed under the terms and conditions of the Creative Commons Attribution (CC BY) license (https:// creativecommons.org/licenses/by/ $4.0 /)$.

\begin{abstract}
Sporting societies around the world are being impacted by a variety of contemporary climatic challenges. The sport management literature indicates that these impacts have disrupted sport. Some adaptations have been implemented, but a comprehensive planning framework is absent from the literature. Learning from other industries, thus, was considered, and an examination of the literature from the water and forestry industries was conducted. The examination resulted in the discovery of six key themes offering insights or practical lessons to guide sport organizations in their efforts to organize for adapting to climatic impacts.
\end{abstract}

Keywords: sport; climatic adaptations; insights for adapting to climatic impacts

\section{Introduction}

Our world's societies are impacted by contemporary climatic challenges [1]. The society of sport is not immune to such challenges, as recently published headline statements from the Intergovernmental Panel on Climate Change-Summary Report (2021) indicated that climate extremes are impacting all regions around the world. These impacts include, for example, "observed changes in extremes such as heatwaves, heavy precipitation, droughts, and tropical cyclones" [1] that have intensified since previous IPCC reports [1].

Sport management literature has noted that climatic impacts have disrupted sport, such as skiing events [2-5]; skating events [6,7]; the Olympic Games [8-11]; the World Cup [12,13]; golf [14,15]; football/soccer [16]; and sports fields [13,17-19]; exemplifying challenges to the use of our natural resources [20].

Sport has implemented some adaptations for the advancing contemporary climatic challenges. Examples include the addition of shade and cooling structures and strategies for athletes [13]; the advance of heat policies [19,21]; and adaptations conducted to manage sports fields during drought conditions as well as extreme rain events $[17,18]$. The literature did not, however, offer a comprehensive planning framework for adapting for climatic challenges by sport. Instead, the adaptations were found to be piecemeal in nature.

It has been noted in other industries that "the majority of research studies stop at the impact assessment stage" [22] and there is a noted lack of knowledge about how to move forward to adapt within industries [23,24]. An interpretation of the lack of sport journal manuscripts on planning for climatic challenges means that this gap also exists within sport. Without an established consensus regarding how to organize sport to move forward, the researchers of this manuscript turned to other industries for insights.

This research examined academic literature from the water and forestry industries for insights that can be applied to guide sport when organizing to adapt to climatic challenges. This examination was forged on the opinion of Eisenack (2014) that knowledge is needed "to assist decision-makers in planning and implementing adaptation actions and policies" [25]. Additionally, the interdisciplinary examination used to advance knowledge on the topic was further supported by Carr (2018), Christensen (2021), Keenan (2015), along with Orr 
and Inoue (2018). It is noted that interdisciplinary research can advance understandings that are shared [26] by raising "a critical thinking and creative consciousness among scholars, contributing to a more holistic, sustainable, and socially robust learning in research" [27]. Also, the use of diverse forms of knowledge [28] can aid in the challenge of climate vulnerabilities [29]. Brown and Wilby (2012) encouraged examinations that offered "an additional advantage of sensitivity approaches [that] ... may preclude the need for an expensive climate impact assessment and associated opportunity costs (i.e., time and money)" [30].

The examination resulted in the discovery of six key themes that offered insights or practical lessons to guide sport in its efforts in adapting to climatic impacts. An interpretation of these insights applied to sport gave rise to actions for sport when organizing for climatic impacts.

\section{Materials and Methods}

The guiding research question was based on an adaptation of the question by Ford, Berrang-Ford and Paterson (2011) and included the following:

RQ: What concrete examples of recommendations, or implemented actions, concerning how to organize to manage climatic impacts are outlined in the research?

To answer this $R Q$, in part, this research used an examination of interdisciplinary academic work from the water and forestry industries and determined the themes and associated insights that were deemed to be applicable for use to guide sport when organizing to adapt for climatic challenges. This research utilized selective sampling [31] and purposeful sampling [32] to identify academic journals in the water and forestry industries. A total of fifteen journals were examined that included:

- Climate

- Climate Change

- Ecology and Society

- Forests

- Hydrology and Earth System Sciences

- International Journal of Biometeorology

- International Journal of the Commons

- Journal of Environmental Planning and Management

- Journal of Forestry

- Journal of Water Resources and Protection

- Mitigation and Adaptation Strategies for Global Change

- Open Journal of Forestry

- $\quad$ Science of the Total Environment

- Small-scale Forestry

- Water

Manuscripts within these journals were examined for concrete examples of insights or practical lessons that could guide sport to establish a framework to adapt to contemporary climatic impacts., such as drivers of adaptations [33] and an overview of adaptation actions and their impacts on policy [34].

\subsection{Data Collection}

The water and forestry industries' academic literature were selected, as both include ancient ecosystems found around the world and are noted as being sensitive to climatic impacts, "as are the societies and economies that depend on them" [28]. The academic literature examined was found in the sampling of journals published from the years 2000-2021. The data collection was guided by typologies developed by Biagini et al. (2014). The six key typologies utilized included a focus on the following: (1) capacity building; (2) management and planning; (3) policy; (4) practice and behavior; (5) warning or observing systems; and (6) financing. Data collection involved screening for the typologies based on a reading of the table of contents. If a manuscript met the screening protocols, 
then the abstract was read. If an abstract outlined that the topic was related to one of the typologies, then the full manuscript was read. Themes from these manuscripts were recorded, along with supporting quotes, during each reading. This assembled the collection of data that was organized within a chart that was further sub-divided into water industry or the forestry industry data. It is important to note that statements in the water or forestry literature were generally focused on a particular case or region. Only statements that were interpreted as generalizable were utilized in this study.

\subsection{Data Analysis}

To answer the research question, in part, the data analysis involved thematic units derived from readings of the data in a search for themes that were then coded [35]. It was noted that "researchers can explore how categories or thematic ideas are represented" [36]. There was a search for themes during each of three readings of the data collected $[35,36]$.

\section{Results}

Academic literature from the water and forestry industries were examined for insights applicable to guide sport when planning to adapt for contemporary climatic challenges. These insights are outlined in Table 1 below.

Table 1. Examples of insights from the water and forestry industries concerning organizing for climatic challenges.

Water Industry Insights

Conduct examinations on specific populations (not general populations):

"The responsible management and consumption of water is a challenge that involves all segments of society" [37]. Yet, it was noted that "most of the studies on water management and consumption issues were conducted with the general population or with educational populations in mind" [37], and were not extended to focus on specific populations.

Systematic evaluations of priorities are necessary

In a study on climate, water, and agriculture in Africa, it was concluded that "the most effective strategies presented promote reduction of the present vulnerability, enhancing the broad spectrum of capacity in response to environmental, economic and resource perturbations" [38]. Systematic evaluations of priorities and constraints along with the involvement of stakeholders was suggested as necessary for process of planning of adaptation strategies [38].

Social learning is critical

Australian coastal water literature indicated that "in order to adapt to climate change, communities need to not only understand the likely risks and impacts but engage in a planning process to consider what can and should be done about them" [39].

Capacity $\begin{aligned} & \text { We need to determine the correct allocation of water resources } \\ & \text { building }\end{aligned}$
"Research on the correct allocation of water resources is becoming increasingly important due to the reduction of water
availability and the increasing competition between different users" [40].
Water management strategies are available in the literature
Kaushal, Gold and Mayer (2017) developed "a predictive and proactive approach [to water management] on an understanding
of both root causes and trends of water degradation and an appreciation for nonstationarity and uncertainty in climate
trends" [41]. Their stages included:
"... increasing interaction between land use and climate change. During the first stage, hydrologic modifications and the built
environment amplify overland flow via processes associated with runoff-dominated ecosystems (e.g., soil compaction,
impervious surface cover, drainage, and channelization). During the second stage, changes in water storage impact the capacity
of ecosystems to buffer extremes in water quantity and quality (e.g., either losses in snowpack, wetlands, and groundwater
recharge or gains in water and nutrient storage behind dams in reservoirs). During the third stage, extremes in water quantity
and quality contribute to losses in ecosystem services and water security (e.g., clean drinking water, flood mitigation, and habitat
availability). During the final stage, management and restoration strategies attempt to regain lost ecosystem structure, function,
and services but need to adapt to climate change. By anticipating the increasing interaction between land use and climate
change, intervention points can be identified, and management strategies can be adjusted to improve outcomes for realistic
expectations. Overall, global water security cannot be adequately restored without considering an increasing interaction
between land use and climate change across progressive stages and our ever-increasing human domination of the water cycle
from degradation to ecosystem restoration" [41].


Table 1. Cont.

\begin{tabular}{|c|c|}
\hline \multirow{18}{*}{$\begin{array}{l}\text { Capacity } \\
\text { building }\end{array}$} & Forest Industry Insights \\
\hline & Social learning is key to successful adaptations \\
\hline & $\begin{array}{l}\text { "the success of the forest groups has been made possible by the explicit organization of a process of social learning, leading to } \\
\text { change in the beliefs and the social norms of forest owners and users" [42]. Further, "the contribution to fostering social learning } \\
\ldots \text { is established ... (1) the recourse to sustainability criteria and indicators as an open-ended learning device, (2) the } \\
\text { experimentation with disruptive action strategies to put new beliefs into practices, and (3) the building of new forms of social } \\
\text { cooperation around these new beliefs and practices" [42]. }\end{array}$ \\
\hline & A key challenge is "accepting that we may not be able to maintain everything that forests have traditionally provided" [28]. \\
\hline & Organic and community-based organizational structures are needed to support change \\
\hline & "avoid creating rigid organizational hierarchies that deter innovation, and be inclusive, open, and questioning" [28]. \\
\hline & "community based management approaches are often argued to be the most successful approach for adaptation" [28]. \\
\hline & Partnerships are critical in the process of change \\
\hline & $\begin{array}{l}\text { "Partnerships that integrate researchers from multiple disciplines with forest managers and local actors can build a shared } \\
\text { understanding of future challenges and facilitate improved decision making in the face of climate change" [28]. }\end{array}$ \\
\hline & $\begin{array}{l}\text { "Effective adaptation will require much greater cooperation between stakeholders, more flexibility for management actions and } \\
\text { commitment of time" [28]. }\end{array}$ \\
\hline & Adaptations have occurred over time ... but pressures today require immediate action \\
\hline & $\begin{array}{l}\text { "Forest ecosystems are resilient and many species and ecosystems have adapted historically to changing conditions, future } \\
\text { changes are potentially of such magnitude or will occur at rates that are beyond the natural adaptive capacity" [28]. }\end{array}$ \\
\hline & The "situation is too uncertain to support long-term and potentially costly decisions that may be difficult to reverse" [28]. \\
\hline & Expect trade-offs and barriers to success \\
\hline & $\begin{array}{l}\text { Trade-offs are necessary "between actions to address mitigation and the provision of local ecosystem services and those for } \\
\text { adaption" [28]. }\end{array}$ \\
\hline & Expected barriers involve "inflexible tenure arrangements and regulatory environments which do not support innovations" [28]. \\
\hline & Impeding success is a failure "to account for the multi-level or polycentric nature of governance: [28]. \\
\hline & $\begin{array}{l}\text { Keenan (2015) stated that due to the pace of climatic impacts and "dynamics that have never previously existed ... } \\
\text { implementing policies and then taking time to learn from them may not be possible .... . so observation of past experience may } \\
\text { be a poor guide for future action. Management will need to be more 'forward-looking', considering the range of possible future } \\
\text { conditions and planning actions that consider the full range" [28]. This implies that "managers will need to consider trade-offs } \\
\text { between different objectives under different conditions" [28]. }\end{array}$ \\
\hline \multirow{10}{*}{$\begin{array}{l}\text { Management } \\
\text { and planning }\end{array}$} & Water Industry Insights \\
\hline & We need to plan today to adapt \\
\hline & $\begin{array}{l}\text { It has been noted that "climate change and extreme variability will force us to adapt to freshwater shortages, alterations in } \\
\text { distribution" [33]. }\end{array}$ \\
\hline & $\begin{array}{l}\text { In an examination of Spanish farmers, it was noted that "the responsible management and consumption of water is a challenge } \\
\text { that involves all segments of society" [37]—and is not industry specific in silos. }\end{array}$ \\
\hline & Multiple collaborations and perspectives and options are critical in the process of planning \\
\hline & $\begin{array}{l}\text { Radhakrishnan et al. (2017)disseminated a framework "to enhance the understanding of any local adaptation context by } \\
\text { structuring the adaptation problem through multiple perspectives" [43]. These researchers suggested that "the pooling together } \\
\text { of adaptation measures derived from multiple perspectives can lead to increased flexibility by way of having a greater number } \\
\text { of adaptation measures and increased pathways to consider" [43]. It was noted that "merely adding more adaptation measures } \\
\text { may not automatically translate into enhanced flexibility" [43]. Enhancing the flexibility of the options "is considered by means } \\
\text { of: (i) identifying the link between adaptation measures; (ii) ascertaining the comparability of the measures with one another; } \\
\text { and (iii) then creating a knowledge base comprising all plausible sequences and time epochs at which the measure could be } \\
\text { deployed based upon the unfolding external factors" [43]. }\end{array}$ \\
\hline & $\begin{array}{l}\text { "The sustainable governance of water resources relies on processes of multi-stakeholder collaborations and interactions that } \\
\text { facilitate the sharing and integration of diverse sources and types of knowledge" [44]. It is "challenging for any one group or } \\
\text { agency to possess the full range of knowledge that is needed" [44]. Successful opportunities were advanced "through the } \\
\text { development of their watershed master plans, as well as through the facilitation of new communicative connections and } \\
\text { translation efforts between diverse stakeholder groups" [44]. The challenges include "limited capacity and resources ... [and] an } \\
\text { ability to facilitate effective knowledge co-creation [44]. }\end{array}$ \\
\hline & Forestry Industry Insights \\
\hline & Complete a risk assessment and establish objectives \\
\hline & $\begin{array}{l}\text { "Effective adaptation requires clear objectives ... risk assessment and management provide a foundation for decision } \\
\text { making" [28]. }\end{array}$ \\
\hline
\end{tabular}


Table 1. Cont.

\begin{tabular}{ll}
\hline & Resources are available to aid the planning process \\
\cline { 2 - 3 } & $\begin{array}{l}\text { Ontl et al. (2019) developed an Adaptation Workbook that incorporates assessments concerning regional vulnerability and then } \\
\text { an overview of adaptation options and tactics to aid implementation. The workbook "integrates region-specific climate change }\end{array}$ \\
$\begin{array}{l}\text { Management } \\
\text { and planning }\end{array}$ & $\begin{array}{l}\text { information with project-level considerations in order to identify on-the-ground adaptation actions to reduce climate risks and } \\
\text { help meet management objectives" [45]. }\end{array}$
\end{tabular}
Currently, adaptations are reactive

Brunette et al. (2018) examined 89 manuscripts on forest adaptation for climate and found adaptations were generally reactive to wildfire risks and included "the existence of a regional bias" [23].

Water Industry Insights

Experiment with policy adaptations

McFadgen and Huitema (2017)stated that "adaption to climate change is an emerging policy field that requires new solutions to largely intractable issues" [46]. These researchers promoted experimenting with climate adaptation water management policies to advance knowledge and understandings of climate risk. "Policy experiments are used to test innovative climate policy solutions in the real world" [46]. Further, it was noted that "a difficult problem such as how to adapt to climate impacts requires an approach that focuses on learning, and experiments are an increasingly favored mode of learning that produce evidence of the effects of an intervention to improve decision-making" [46]. The results indicated that a common goal can be developed through experimentation; however, a caveat concerning using experimentation in policy development was offered that indicated "but they will not harmonise conflicting views in a group by changing perspectives and views" [46].

Forestry Industry Insights

Policies that support adaptations are necessary

Policy There is a need for "the creation of new policies or revisions of policies or regulations to allow flexibility to adapt" [34].

"Whilst policies that support economic diversification will be important, this may involve diversification well beyond traditional sectors" [28].

Importantly, “having the right policies can send a strong political signal that adaptation needs to be considered seriously but flexibility in policy systems will be required to facilitate adaptive planning" [28].

De Zoysa and Inoue (2014) indicated that in Sri Lanka's forestry industry, the policy environment included: "changing regulations and legislation, developing awareness and capacity, planning for climate-smart agroforest landscapes, offering no-regret option and implementing climate change adjustment programs are discussed as important policy measures" [47].

Murthy and Kumar (2019) stated that in the forestry industry, "climate proofing of vulnerable sectors, programmes, natural systems and communities by integrating adaptation and mitigation options into planning processes are increasingly becoming an integral part of development. The forestry policies formulated so far in India have been broadly aimed at conservation, reduction of pressure on forests and provisioning of biomass to the large forest dependent population for their fuel and fodder needs ... However, these have been formulated with climate change as a consideration and therefore, may become less effective as climate change and its impacts become increasingly evident" [48].

Water Industry Insights

Adapting practices and behaviors are necessary for a variety of reasons

There is a need to increase the capacity of surface-water retention to safeguard the water table [49]

"Among different users of freshwater, irrigation is the most impacting groundwater resources leading to water table depletion" [49].

Yapiyev et al. (2017) stated that "open reservoirs ... have substantial water loses through evaporation" [50].

Adaptations involve a complex array of elements

Feldman (2013) concluded that adaptations in the water industry for climatic issues require "(1) better communication between scientists and end-users, (2) adaptive management—an approach emphasizing social learning and incremental solutions that are

Practice and reversible if they fail ..., and (3) recognition that ... knowledge and effective collaboration go together-experts must reach out" [33].

"revisions or expansion of practices and on the ground behavior that are directly related to building resilience" [34].

Climatic impacts mean "taking into account the water resource losses due to climate change scenarios ... [and] accounting for the expected reduced availability of water resources in the context of climate change" [40].

A new concept has emerged that influences practice and behavior

"The water-energy-food nexus ... has emerged in the last decade ... [and] indicates that water security, energy security, and food security are inextricably linked and that actions in any one area generally impact one or both of the other sectors" [50]. This means that a coordinated approach between the three areas is necessary. Further, "the role of water in the water-energy-food nexus is crucial as it is an enabler, whereas in the areas dominated by water scarcity it limits food and energy production" [50].

"With unprecedented shifts in climate and land use change, and a rapidly changing political climate, it is essential that ICM [integrated catchment management] evolves to balance competing demands for different ecosystem services across what has been coined the water-energy-food nexus" [20]. 
Table 1. Cont.

\begin{tabular}{|c|c|}
\hline \multirow{8}{*}{$\begin{array}{l}\text { Practice and } \\
\text { behavior }\end{array}$} & The literature offers adaptation insights concerning water resources \\
\hline & $\begin{array}{l}\text { Yapivev et al. (2017) recommended the use of "shade or sheltering structures" [or] an innovative solution ... a technology } \\
\text { involving floating solar covers. The floating photovoltaic system is a new concept in energy technology that can meet current } \\
\text { energy needs and allow for successful adaptation to the changes in climate" [50]. This technology aids in decreasing evaporation } \\
\text { and has the bonus of generating energy at the same time. }\end{array}$ \\
\hline & $\begin{array}{l}\text { Liu and Chui (2017) examined "water runoff and permeable pavement (PP)". Their "study generated insights that will help the } \\
\text { design and implementation of PP runoff reduction" [51]. It was noted that the "thickness of the storage layer and the hydraulic } \\
\text { conductivity of the subgrade" [51] are considered as important factors in this technology. }\end{array}$ \\
\hline & $\begin{array}{l}\text { In their study of farmers' perspectives concerning water consumption practices, "most agreed that investing in more efficient } \\
\text { irrigation techniques would allow for times of drought to be endured" [37]. }\end{array}$ \\
\hline & Forest Industry Insights \\
\hline & Meet objectives by using personal experiences in the communications \\
\hline & $\begin{array}{l}\text { When it comes to communicating awareness for and climatic actions, it requires that "practitioners should learn how to better } \\
\text { tailor climate change communication to the personal experiences and decision-making needs of their target audience and } \\
\text { involve trusted peers and information channels" [52]. }\end{array}$ \\
\hline & $\begin{array}{l}\text { "Devising strategies that are able to meet management objectives under a range of scenarios is likely to be the most robust } \\
\text { approach" [28]. }\end{array}$ \\
\hline \multirow{4}{*}{$\begin{array}{l}\text { Warning or } \\
\text { observing } \\
\text { systems }\end{array}$} & Water Industry Insights \\
\hline & Warnings concerning the climatic issues are needed \\
\hline & $\begin{array}{l}\text { "The unbalance between the availability of water resources and demand is currently exacerbated and could become worse in the } \\
\text { near future" [49]. }\end{array}$ \\
\hline & $\begin{array}{l}\text { There is the need for the "implementation of new or enhanced tools and technology for communicating weather and climate } \\
\text { risks, and for monitoring changes in the climate system" [34]. }\end{array}$ \\
\hline \multirow{3}{*}{ Financing } & Water Industry Insights \\
\hline & Underlying financial support is needed \\
\hline & $\begin{array}{l}\text { "new financing or insurance strategies to prepare for future climate disturbances" [34]; however, examples of the development } \\
\text { of new financing and insurance strategies were not found in the literature. }\end{array}$ \\
\hline
\end{tabular}

\section{Discussion}

The examination resulted in the discovery of six key themes offering insights or practical lessons to guide sport organizations in their efforts to organize for adapting to climatic impacts. Each theme will now be presented.

\subsection{Theme 1: Organize for Social Learning}

Insights derived from the examination of literature suggested that organizational structures need to be designed to support the following elements: (a) social learning [33,42,44], (b) cooperation between stakeholders, and (c) encouraging adaptive capacity [28]. This means steering away from hierarchical structures that may impede the development of adaptation innovations [28] and moving towards organic methods of organization that promote inclusivity. It was noted that these inclusive structures support open-ended learning [42] with multiple partnerships for "multi-stakeholder collaborations and interactions" [44] or a community-based approach that is "often argued to be the most successful approach for adaptation" [44]. Furthermore, and importantly, the multiple perspectives help to overcome local or regional bias [23]. Partnerships, with the inclusion of local participants and researchers/scientists from different disciplines [28,33] can offer wide ranging types of knowledge that can be shared [44]. This can advance the understandings of the complex topic and support the range of knowledge needed to meet a variety of climatic challenges $[42,44]$. Overall, the organizational structure needs to support a process of planning for climatic impacts.

\section{An Application of Theme 1 Insights to Sport}

An interpretation of the insights from theme 1 mean that when sport is organizing to tackle climatic challenges, an organic organizational structure should be used that 
is open to the inclusion of multiple partnerships (including all levels of sport and researchers/scientists from multiple disciplines) to advance knowledge about the climatic impacts through open-ended learning and cooperation to aid in the process of generating plans for climate-proofing sport.

\subsection{Theme 2: Fundamental Communications Are Critical}

It was noted in the water and forestry literature that fundamental communications for communities seeking to adapt to climatic issues include (a) promoting understandings of the climatic impacts, (b) that the multiple stakeholders are part of the planning process to determine next steps [39], and (c) that change should be expected [28]. An insight for communicating this knowledge involves tailoring messaging "to the personal experiences and decision-making needs of their target audience and involve trusted peers and information channels" [52]. Furthermore, it is important that the communications promote that change for climatic challenges is aimed at reducing vulnerability [38] and that it may mean a full return to traditional activities that were previously provided may not be possible [28] This is because of the "changing conditions, [and] future changes are potentially of such magnitude or will occur at rates that are beyond the natural adaptive capacity" [28] (p. 146). This situation enhances the "need for better communication between scientists and endusers" [33], as well as communication efforts to aid in the translation of the knowledge for each of the stakeholder groups [44]. Overall, it means that communications need to promote an openness "to change in beliefs and the social norms" [42] in the process of climate-proofing society's vulnerable sectors [28,48]. Additionally, a recommendation is that "new or enhanced tools and technology for communicating weather and climate risks, and for monitoring changes in the climate system" [34] be developed.

\section{An Application of Theme 2 Insights to Sport}

An interpretation of insights from theme 2 means that those in sport leadership positions should establish communications with the sporting community to update them on their local/regional climatic impacts—this includes messaging from researchers/scientists as well as translations for improved understandings of the messages. Additionally, the communications can be used to encourage the multiple stakeholders in sport to be part of the planning process for moving forward and be open to change to generate sport for the future. The messaging should include personal experiences from those in sport, such as adaptations that have already been implemented within the region and by sport around the world. Additionally, the communications should promote an openness for change. One such example may involve outlining how sport has changed over the decades, but, illustrating that the pace of change has increased, the adaptations must keep up, and this may mean sport will be different in the future. The development of communication channels specifically for sport can be used to enhance understandings of climate risks, monitoring activities, and the need for sport to adapt for such risks.

\subsection{Theme 3: All Societies and Organizations Should Expect Challenges concerning Water}

One key topic consistently discussed in both the water and forestry literature involved issues surrounding water resource availability. Climate-induced water issues are expected to increase [49] with implications for "all segments of society" [37]. There is an expectation that climate variability and extremes "will force us to adapt to freshwater shortages, [and] alterations in distribution" [33]. This means that there is an expected reduction of water resource availability [40], rising water demand [49], as well as increased competition between user groups [40]. Currently, there is a noted lack of understanding concerning the specific water consumption and management requirements for most segments of society, as studies have been generalized [37] rather than focused on specific populations. Research, thus, on water allocation is a growing priority [40]. To assist in developing understandings concerning water, Kaushal, Gold and Mayer (2017) developed "a predictive and proactive approach [to water management] on an understanding of both root causes 
and trends of water degradation ... and uncertainty in climate trends" [41]. They offered a staged strategy that encompassed hydrologic modifications, water storage, water quantity and quality, along with management and restoration strategies. The growing need for a proactive approach stems from understandings that freshwater used for irrigation purposes is "impacting groundwater resources leading to water table depletion" [49] and catchment strategies are, thus, necessary [20]. Open reservoir catchments are experiencing greater evaporation, and shade structures are now necessary [50]. An innovative technology is a solar cover that floats and decreases evaporation while generating energy [50]. Other ideas discussed include permeable pavement [51] and investing in the latest irrigation equipment and techniques [37].

Interestingly, a new concept has arisen in the past decade on the water-energy-food nexus that "indicates that water security, energy security, and food security are inextricably linked and that actions in any one area generally impact one or both of the other sectors" [50]. This means that a coordinated approach is vital between the three areas. The role of water, however, is "crucial as it is an enabler, whereas in the areas dominated by water scarcity it limits food and energy production" [50]. This gives rise to the question as to where other organizations and industries are positioned concerning their priority for accessing water resources.

\section{An Application of Theme 3 Insights to Sport}

An interpretation of insights from theme 3 means that sport should expect climateinduced water issues that include shortages of freshwater and rising competition. This means that sport should begin their water-management plan with research that develops an understanding of the water issue with respect to specific sporting populations. A guiding document is the Kaushal, Gold and Mayer (2017) proactive approach that has the potential to be adapted for sport. Special consideration should be given to reducing freshwater irrigation and the advance of catchment strategies with evaporation or shade structures. The interconnected elements in the water-energy-food nexus indicates that sport will need to meet the challenge of gaining access to water resources over energy and food requirements among a crowded group of societies/organizations with a need for water.

\subsection{Theme 4: Devise Action Plan Options for Climatic Challenges}

Importantly, the pace of the climatic impacts means that:

"Future climatic conditions may result in system states and dynamics that have never previously existed ... , so observation of past experience may be a poor guide for future action. Management will need to be more 'forward-looking', considering the range of possible future conditions and planning actions that consider the full range" [28].

There was, thus, support for immediate action planning for climatic challenges. These plans include systematic evaluations to delineate priorities [38] and objectives [28], along with encouraging multiple perspectives that are needed to advance a full range of adaptation options and implementation practices $[43,44]$. It was noted that trade-offs are needed between the various objectives under different noted conditions [28]. Interestingly, an insight involved the use of an incremental adaptive approach that is open to reversing any selected action that fails to solve the issue as predicted [33]. This approach was also seen as important when selecting adaptation actions as the "situation is too uncertain to support long-term and potentially costly decisions that may be difficult to reverse" [28].

Frameworks were offered to aid in devising an action plan for climatic impacts. For example, Ontl et al. (2019) developed an 'Adaptation Workbook' that incorporates assessments pertaining to regional vulnerability and then an overview of adaptation options and tactics to aid implementation. The workbook "integrates region-specific climate change information with project-level considerations in order to identify on-the-ground adaptation actions to reduce climate risks and help meet management objectives" [45]. Radhakrishnan et al. (2017) disseminated a framework for "creating a knowledge base comprising all plausible sequences and time epochs at which the measure could be deployed based upon the 
unfolding external factors" [43]. The framework encourages multiple perspectives to generate a record or listing of all options presented and the consolidation of the perspectives for use. The Radhakrishnan research team noted that "merely adding more adaptation measures [to the list] may not automatically translate into enhanced flexibility" [43]; instead, they suggested:

1. Identifying the link between adaptation measures.

2. Ascertaining the comparability of the measures with one another; and

3. Then creating a knowledge base comprising all plausible sequences and time epochs at which the measure could be deployed based upon the unfolding external factors [43].

Interestingly, Biagini et al. (2014) recommended societies find "new financing or insurance strategies to prepare for future climate disturbances" [34]. Meanwhile, Keenan (2015) and Medema et al. (2017) indicated that barriers were expected in the process of developing an action plan for climate impacts. Keenan (2015) stated that such barriers involve "inflexible tenure arrangements and regulatory environments which do not support innovations" [28]. Meanwhile, Medema et al. (2017) stated that a barrier was a challenge of "limited capacity and resources ... [and] an ability to facilitate effective knowledge co-creation [44].

An Application of Theme 4 Insights to Sport

An interpretation of insights from theme 4 means sport should move forward with an adaptation of the frameworks outlined in the water and forestry literature rather than generating such documents from scratch. Examples of frameworks include adapting the Ontl et al. (2019) "Adaptation Workbook" to expose sports climatic vulnerabilities, pulling together adaptation options and tactics for implementation, and the Radhakrishnan et al. (2017) framework for managing options.

Water is used as an example of an area where action planning options are needed, as all societies are going to be challenged relative to water-including the society of sport. A lack of clean water for athletes to drink can jeopardize their health; additionally, a lack of water necessary for maintaining grass-based sports fields can place these fields in jeopardy over time. We now offer examples of options concerning water resources to begin the process of devising options for climatic challenges-but it is important to note that they are deemed to be a starting place to encourage debate and do not constitute a full list. One option is to advance water access through sport facility catchment strategieswith solar shade to reduce evaporation, including a new technology involving floating solar covers [50] - and water reuse strategies at all sport facilities. Furthermore, sport can begin experimenting with the removal of grass for sports fields. Can sports such as cricket, football, and rugby be played on compacted sand, or clay, or a combination of the two? This is simply the application of different playing surfaces that can be used in tennis being expanded to other sports. Additionally, which sports could be played on pea gravel? Such adaptations have given rise to volleyball being played on beach courts. Experimentations today can prepare sport to adapt and give rise to niche sports options for the eventuality of greater increasing competition for water resources. This type of adaptation is promoted in this research manuscript based on Kale's (2013) position that encouraged the "systematic evaluation of priorities" [38] in the water industry. An application of this position in sport entails that the continuation of sport, despite water resources' impacts on grass-based sports fields, is a priority. Additionally, experiments today provide an opportunity to determine measures that are acceptable to sporting participants, and to advance knowledge concerning the application of such options, such as impacts from internal and external factors. An interpretation is that sport will not avoid the noted barriers to adaptation, including limited resources [44] along with conflicting views to a harmonized way forward [46]. 


\subsection{Theme 5: Begin Experimenting with Policy Solutions}

McFadgen and Huitema (2017) stated that policy adaptions for climatic impacts is an emerging policy field. There is a need to establish new policies, or to revise current policies, in the process of adapting to climatic impacts [34]. The literature recommended a strategy of experimentation, rather than determining adaptations with immediate full implementation [28,42,46]. Experimentation allows for the testing of actions and the building of evidence concerning the correct action [46] along with "the building of new forms of social cooperation around these new beliefs and practices" [42]. Additionally, this strategy sends a message that adaptive planning is a serious activity, but the flexibility to get it right is important [28] to ensure resilience is being advanced [34]. Further, it was noted as supporting the production of "evidence of the effects of an intervention to improve decision-making" [46].

\section{An Application of Theme 5 Insights to Sport}

An interpretation of insights from theme 5 means sport should begin experimenting with policy adaptations for climatic impacts. The time is at hand, as the pace of climatic impacts is accelerating [28]; therefore, there is no time to waste, especially when the process requires time to organize for social learning; advance fundamental communications; devise and manage action options (such as for water challenges facing "all segments of society" [37]; and then to experiment with policy solutions.

\subsection{Theme 6: Continuously Revise Policies}

Due to the rate of change with respect to the climatic impacts, policy adaptations need to be flexible and be open to continuous adaptations over time [34,47]. This means that there is a need to monitor each new or renewed policy to ensure they have not lost their effectiveness over time [48]. The monitoring allows the policies to be updated based on the arising scenarios and knowledge advanced throughout the process of adapting for climatic impacts [28].

\section{An Application of Theme 6 Insights to Sport}

An interpretation of insights from theme 6 means sport should establish a strategy for monitoring policy adaptations for climatic impacts over time. Further, there needs to be an openness to ensuring the sport policies are flexible and can be continuously adapted for climatic impact adaptations.

\section{Conclusions}

This research examined academic literature from the water and forestry industries for insights that were applied to guide sport when organizing to adapt to climatic challenges. The examination resulted in the discovery of six key themes offering insights or practical lessons to guide sport in their efforts to adapt to climatic impacts. Further comparative research, such as from the agriculture and tourism industries, can add to the understandings of adaptation strategies for climate. The key themes and conclusions are outlined in Table 2 below.

Table 2. Contributions of the insights from the water and forestry industries applied to guide sport when adapting for climatic challenges.

\begin{tabular}{ccl}
\hline Theme & $\begin{array}{c}\text { Contributions of the Learning from the Water and Forestry Industries that were } \\
\text { Applied to Guide Sport When Adapting for Climatic Challenges }\end{array}$ \\
\hline Theme $1 \quad \begin{array}{l}\text { Organize for social } \\
\text { learning }\end{array}$ & $-\quad \begin{array}{l}\text { Steer away from hierarchical organizational structures } \\
\text { Develop organic networks that are supportive of social learning as well as } \\
\text { open-ended learning }\end{array}$ \\
& $\begin{array}{l}\text { Encourage multiple partnerships and cooperation at all levels of sport (including local, } \\
\text { regional and beyond, along with researchers/scientists from multiple } \\
\text { applicable disciplines) } \\
\text { Inclusivity is key for a community-based approach of knowledge sharing and for } \\
\text { generating plans for climate-proofing sport }\end{array}$ \\
\hline
\end{tabular}


Table 2. Cont.

\begin{tabular}{|c|c|c|}
\hline & Theme & $\begin{array}{l}\text { Contributions of the Learning from the Water and Forestry Industries that were } \\
\text { Applied to Guide Sport When Adapting for Climatic Challenges }\end{array}$ \\
\hline Theme 2 & $\begin{array}{l}\text { Fundamental } \\
\text { communications are } \\
\text { critical }\end{array}$ & $\begin{array}{l}\text { - Improve communication linkages between researchers/scientists and those in sport, } \\
\text { including advancing translations for improving understandings } \\
\text { - } \\
\text { Ensure the communications include the use of personal experiences of those in sport } \\
\text { concerning climatic impacts and adaptation strategies } \\
\text { Promote the need for adaptations, the development of goals, objectives, and strategies } \\
\text { to meet the goals and objectives } \\
\text { - Communicate the magnitude and pace of the changing environmental conditions } \\
\text { impacting sport, that the need to adapt is imminent, and that their voices are needed } \\
\text { throughout the process } \\
\text { - Communicate that a full return to every tradition in sport may not be possible }\end{array}$ \\
\hline Theme 3 & $\begin{array}{l}\text { All societies and } \\
\text { organizations should } \\
\text { expect challenges } \\
\text { concerning water }\end{array}$ & $\begin{array}{l}\text { - Promote that sport needs to understand the current water-consumption situation (i.e., } \\
\text { how much water is used to maintain grass-based sports fields annually) } \\
\text { Indicate that sport is challenged to obtain future water resources in the } \\
\text { water-energy-food nexus and adaptations will be necessary by sport throughout } \\
\text { the world } \\
\text { - Communicate that sport needs a water-management plan to safeguard } \\
\text { water resources } \\
\text { - Consider adapting the Kaushal, Gold, and Mayer (2017) proactive guiding document } \\
\text { concerning adaptations }\end{array}$ \\
\hline Theme 4 & $\begin{array}{l}\text { Devise action plan } \\
\text { options for climatic } \\
\text { challenges }\end{array}$ & $\begin{array}{l}\text { - Pull together all options and tactics for managing the mitigating climatic impacts } \\
\text { on sport } \\
\text { - } \quad \text { Ensure all parties within sport are invited to contribute and all ideas are recorded } \\
\text { and considered } \\
\text { - Consider using resources that can be adapted for sport, such as the Ontle et al. (2020) } \\
\text { "Adaptation Workbook" and the framework by Radhakrishnan et al. (2017) on } \\
\text { generating a record of all perspectives and options and consolidating them for use } \\
\text { - } \quad \text { Expect to have to navigate barriers } \\
\text { - Options were outlined in the discussion above concerning the issue of water and sport } \\
\text { to start the debate on adaptations } \\
\text { Implement an incremental adaptive approach open to reversing any selected options } \\
\text { that are not successful during implementation experiments }\end{array}$ \\
\hline Theme 5 & $\begin{array}{l}\text { Begin experimenting } \\
\text { with policy solutions }\end{array}$ & $\begin{array}{l}\text { - } \quad \text { Begin experimenting with some of the options } \\
\text { - } \quad \text { Establish new or revised sport policies as learning is advanced from the } \\
\text { experimental actions }\end{array}$ \\
\hline Theme 6 & $\begin{array}{l}\text { Continuously revise } \\
\text { policies }\end{array}$ & $\begin{array}{l}\text { Monitor the new or revised sport policies for their success in managing or mitigating } \\
\text { climatic impacts on sport, and continuously seek to revise and improve such policies }\end{array}$ \\
\hline
\end{tabular}

Overall, sport's preparedness for contemporary climate impacts is lacking and a push is made for additional research to fully access the climatic impacts on sport. Additionally, this research manuscript encourages action in establishing organic structures for social adaptation learning in sport; facilitating inclusivity, collaborations, partnerships; and, importantly, identifying adaptation options for climate-proofing sport. Further research is needed on adaptation options and experimentation, including how to evaluate each option and determine the successful strategies for the future. A push for this type of research is underscored by the Eisenack et al. (2014) statement that the "implementation of adaptation is not keeping pace with the ever-increasing need: the 'adaptation deficit' is getting wider" [25]. Due to this pressure, there is an urgent need for research in sport and climatic impacts.

It is important to note that the results of this research were generalized for use by sport. A limitation is that there is a paucity of research in this topic area to verify the results. Much work is still to be completed in future associated lines of research to advance a robust body of knowledge on the subject. 
Author Contributions: Conceptualization, G.D.; methodology, C.M.; validation, C.M.; G.D.; formal analysis, C.M.; investigation, C.M.; G.D.; writing-original draft preparation, C.M.; writing-review and editing, C.M.; G.D. All authors have read and agreed to the published version of the manuscript.

Funding: This research received no external funding.

Institutional Review Board Statement: Not applicable.

Informed Consent Statement: Not applicable.

Data Availability Statement: Not applicable.

Conflicts of Interest: The authors declare no conflict of interest.

\section{References}

1. Intergovernmental Panel on Climate Change (IPCC). Summary for Policymakers. In Climate Change 2021: The Physical Science Basis; Contribution of Working Group I to the Sixth Assessment Report of the Intergovernmental Panel on Climate Change; Masson-Delmotte, V., Zhai, P., Pirani, A., Connors, S.L., Pean, C., Berger, S., Caud, N., Chen, Y., Goldfarb, L., et al., Eds.; Cambridge University Press: Cambridge, UK, 2021; in press.

2. Dawson, J.; Scott, D. Managing for climate change in the alpine ski sector. Tour. Manag. 2013, 35, 244-254. [CrossRef]

3. Falk, M.; Hagsten, E. Climate change threats to one of the world's largest cross-country skiing races. Clim. Chang. 2017, 143, 59-71. [CrossRef]

4. Landauer, M.; Sievänen, T.; Neuvonen, M. Adaptation of Finnish cross-country skiiers to climate change. Fenn.-Int. J. Geogr. 2009, $187,99-113$.

5. Scott, D.; McBoyle, G. Climate change adaptation in the ski industry. Mitig. Adapt. Strat. Glob. Chang. 2006, 12, 1411-1431. [CrossRef]

6. Fairley, S.; Ruhanen, L.; Lovegrove, H. On frozen ponds: The impact of climate change on hosting pond hockey tournaments. Sport Manag. Rev. 2015, 18, 618-626. [CrossRef]

7. Visser, A.; Petersen, A. The likelihood of holding outdoor skating marathons in the Netherlands as a poli-cy-relevant indicator of climate change. Clim. Chang. 2009, 93, 39-54. [CrossRef]

8. Honjo, T.; Seo, Y.; Yamasaki, Y.; Tsunematsu, N.; Yokoyama, H.; Yamato, H.; Mikami, T. Thermal comfort along the marathon course of the 2020 Tokyo Olympics. Int. J. Biometeorol. 2018, 62, 1407-1419. [CrossRef] [PubMed]

9. Scott, D.; Steiger, R.; Rutty, M.; Johnson, P. The future of the Olympic Winter Games in an era of climate change. Curr. Issues Tour. 2014, 18, 913-930. [CrossRef]

10. Scott, D.; Rutty, M.; Steiger, R. Climate change and the future of the Winter Olympic Games. J. Olymp. Hist. 2015, $23,52-61$. [CrossRef]

11. Vanos, J.K.; Kosaka, E.; Iida, A.; Yokohari, M.; Middel, A.; Scott-Fleming, I.; Brown, R.D. Planning for spectator thermal comfort and health in the face of extreme heat: The Tokyo 2020 Olympic marathons. Sci. Total Environ. 2018, 657, 904-917. [CrossRef]

12. Matzarakis, A.; Fröhlich, D. Sport events and climate for visitors-The case of FIFA World Cup in Qatar. Int. J. Biometeorol. 2014, 59, 481-486. [CrossRef]

13. Sofotasiou, P.; Hughes, B.R.; Calautit, J.K. Qatar 2022: Facing the FIFAWorld Cup climatic and legacy challenges. Sustain. Cities Soc. 2015, 14, 16-30. [CrossRef]

14. Scott, D.; Jones, B. A regional comparison of the implications of climate change for the golf industry in Canada. Canadian Geographer Géographe Canadien 2007, 51, 219-232. [CrossRef]

15. Scott, D.; Jones, B. The Impact of Climate Change on Golf Participation in the Greater Toronto Area (GTA): A Case Study. J. Leis. Res. 2006, 38, 363-380. [CrossRef]

16. Nybo, L.; Flouris, A.D.; Racinais, S.; Mohr, M. Football facing a future with global warming: Perspectives for players health and performance. Br. J. Sports Med. 2020, 55, 297-298. [CrossRef] [PubMed]

17. Dingle, G.; Mallen, C. Community sports fields and atmospheric climate impacts: Australian and Canadian perspectives. Manag. Sport Leis. 2020, 26, 1-25. [CrossRef]

18. Dingle, G.; Stewart, B. Playing the climate game: Climate change impacts, resilience and adaptation in the climate-dependent sport sector. Manag. Sport Leis. 2018, 23, 293-321. [CrossRef]

19. Mallen, C.; Dingle, G. Climate Change and Canadian Communities' Grass-based Sport Fields. Int. J. Environ. Sustain. 2017, 13, 45-59. [CrossRef]

20. Stosch, K.C.; Quilliam, R.S.; Bunnefeld, N.; Oliver, D.M. Managing Multiple Catchment Demands for Sustainable Water Use and Ecosystem Service Provision. Water 2017, 9, 677. [CrossRef]

21. Chalmers, S.; Jay, O. Australian community sport extreme heat policies: Limitations and opportunities for im-provement. J. Sci. Med. Sport 2018, 21, 544-548. [CrossRef] [PubMed]

22. Wilby, R.L.; Dessai, S. Robust adaptation to climate change. Weather 2010, 65, 180-185. [CrossRef]

23. Brunette, M.; Bourke, R.; Hanewinkel, M.; Yousefpour, R. Adaptation to Climate Change in Forestry: A Multiple Correspondence Analysis (MCA). Forests 2018, 9, 20. [CrossRef] 
24. Ford, J.D.; Berrang-Ford, L.; Paterson, J. A systematic review of observed climate change adaptation in developed nations. Clim. Chang. 2011, 106, 327-336. [CrossRef]

25. Eisenack, K.; Moser, S.; Hoffman, E.; Klein, R.; Oberlack, C.; Pechan, A.; Rotter, M.; Termeer, C. Ex-plaining and overcoming barriers to climate change adaptation. Nat. Clim. Chang. 2014, 4, 867-872. Available online: www.nature.com/natureclimatechange (accessed on 12 May 2021). [CrossRef]

26. Carr, G.; Loucks, D.P.; Blöschl, G. Gaining insight into interdisciplinary research and education programmes: A framework for evaluation. Res. Policy 2018, 47, 35-48. [CrossRef]

27. Christensen, J.; Ekelund, N.; Melin, M.; Widén, P. The Beautiful Risk of Collaborative and Interdisciplinary Research. A Challenging Collaborative and Critical Approach toward Sustainable Learning Processes in Academic Profession. Sustainability 2021, 13, 4723. [CrossRef]

28. Keenan, R.J. Climate change impacts and adaptation in forest management: A review. Ann. For. Sci. 2015, 72, 145-167. [CrossRef]

29. Orr, M.; Inoue, Y. Sport versus climate: Introducing the climate vulnerability of sport organizations framework. Sport Manag. Rev. 2018, 22, 452-463. [CrossRef]

30. Brown, C.; Wilby, L. An alternative approach to assessing climate risks. EOS Trans. Am. Geophys. Union 2012, 93, 401-412. [CrossRef]

31. Sandelowski, M.; Holditch-Davis, D.; Harris, B. Using qualitative and quantitative methods. In Qualitative Methods in Family Research; Gilgun, J., Daly, K., Handel, G., Eds.; Sage Publications: Thousand Oaks, CA, USA, 1992; pp. 301-323.

32. Miles, M.; Huberman, A.; Saldana, J. Qualitative Data Analysis: A Methods Sourcebook; Sage Publications: Thousand Oaks, CA, USA, 2014.

33. Feldman, D.L. Adaptation as a Water Resource Policy Challenge-Institutions and Science. J. Water Resour. Prot. 2013, 5, 1-6. [CrossRef]

34. Biagini, B.; Bierbaum, R.; Stults, M.; Dobardzic, S.; McNeeley, S.M. A typology of adaptation actions: A global look at climate adaptation actions financed through the Global Environment Facility. Glob. Environ. Chang. 2014, 25, 97-108. [CrossRef]

35. Glesne, C. Becoming Qualitative Researchers: An introduction, 5th ed.; Pearson: Boston, MA, USA, 2014.

36. Gibbs, G. Analyzing Qualitative Data; Sage: Thousand Oaks, CA, USA, 2007. [CrossRef]

37. Tójar-Hurtado, J.-C.; Rodríguez, E.M.; Jiménez, M.F. Spanish Agriculture and Water: Educational Implications of Water Culture and Consumption from the Farmers' Perspective. Water 2017, 9, 964. [CrossRef]

38. Kale, G. A modified combined approach framework of climate impact and adaptation assessment for water resource systems based on experience derived from different adaptation studies in the context of climate change. J. Water Resour. Protect. 2013, 5, 1210-1218. [CrossRef]

39. McInnes, K. Global warming, seal level rise and impacts on coastal zones in Australia. In Proceedings of the International Symposium on Coastal Zones and Climate Change: Assessing the Impacts and Developing Adaptation Strategies, Melbourne, Australia, 12-13 April 2010.

40. Maiolo, M.; Mendicino, G.; Pantusa, D.; Senatore, A. Optimization of Drinking Water Distribution Systems in Relation to the Effects of Climate Change. Water 2017, 9, 803. [CrossRef]

41. Kaushal, S.S.; Gold, A.J.; Mayer, P.M. Land Use, Climate, and Water Resources—Global Stages of Interaction. Water 2017, 9 , 815. [CrossRef] [PubMed]

42. Dedeurwaerdere, T. Social Learning as a Basis for Cooperative Small-Scale Forest Management. Small-Scale For. 2009, 8, 193-209. [CrossRef]

43. Radhakrishnan, M.; Pathirana, A.; Ashley, R.; Zevenbergen, C. Structuring Climate Adaptation through Multiple Perspectives: Framework and Case Study on Flood Risk Management. Water 2017, 9, 129. [CrossRef]

44. Medema, W.; Adamowski, J.; Orr, C.; Furber, A.; Wals, A.; Milot, N. Building a Foundation for Knowledge Co-Creation in Collaborative Water Governance: Dimensions of Stakeholder Networks Facilitated through Bridging Organizations. Water 2017, 9, 60. [CrossRef]

45. Ontl, A.T.; Janowiak, M.K.; Swanston, C.W.; Daley, J.; Handler, S.; Cornett, M.; Hagenbuch, S.; Handrick, C.; McCarthy, L.; Patch, N. Forest Management for Carbon Sequestration and Climate Adaptation. J. For. 2019, 118, 86-101. [CrossRef]

46. McFadgen, B.; Huitema, D. Learning our way our via experimentation: A multi-case analysis of how design in-fluences learning outcomes in policy experiments for climate adaptation. Water 2017, 9, 648. [CrossRef]

47. De Zoysa, M.; Inoue, M. Climate Change Impacts, Agroforestry Adaptation and Policy Environment in Sri Lanka. Open J. For. 2014, 4, 439-456. [CrossRef]

48. Murthy, I.; Kuman, P. Forest policies and progammes in India: Implications for climate change adaptations. Open J. For. 2019, 9, 226-240. Available online: http:/ / www.scirp.org/journal/ojf (accessed on 12 May 2021).

49. Guyennon, N.; Salerno, F.; Portoghese, I.; Romano, E. Climate Change Adaptation in a Mediterranean Semi-Arid Catchment: Testing Managed Aquifer Recharge and Increased Surface Reservoir Capacity. Water 2017, 9, 689. [CrossRef]

50. Yapiyev, V.; Sagintayev, Z.; Inglezakis, V.J.; Samarkhanov, K.; Verhoef, A. Essentials of Endorheic Basins and Lakes: A Review in the Context of Current and Future Water Resource Management and Mitigation Activities in Central Asia. Water 2017, 9, 798. [CrossRef] 
51. Liu, C.Y.; Chui, T.F.M. Factors Influencing Stormwater Mitigation in Permeable Pavement. Water 2017, 9, 988. [CrossRef]

52. Vulturius, G.; André, K.; Swartling, G.; Brown, C.; Rounsevell, M. Successes and shortcomings of climate change communication: Insights from a longitudinal analysis of Swedish Forest owners. J. Environ. Plan. Manag. 2019, 63, 1177-1195. [CrossRef] 